\title{
Chapter 13 \\ Labour Migration and Gendered Agricultural Asset Shifts in Southeastern Mexico: Two Stories of Farming Wives and Daughters
}

\author{
Birgit Schmook, Claudia Radel and Ana Crisol Méndez-Medina
}

Keywords Mexico $\cdot$ Labour migration $\cdot$ Agricultural change $\cdot$ Female property rights

\subsection{Introduction}

In this chapter, we present evidence of two gendered agricultural asset shifts associated with labour out-migration in the municipality of Calakmul, Campeche. The first is a shift in land rights from men to women (wives), which occurred as men's labour out-migration, largely to the U.S., coincided with the process of land privatisation and the reform of the ejidal system in Mexico. Ejidos are collective land tenure institutions dating back to the Mexican Revolution and the redistribution of land in the previous century. The second is a more recent shift-one that entails the labour migration of younger single women (daughters) from ejidal villages to nearby cities, the generation of cash earnings, and the subsequent household acquisition of land and cattle back in their home villages. Although Mexico initiated a process of ejidal land parcelisation and privatisation in the mid-1990s (De Janvry and Sadoulet 1997), the ejido remains the most important institution of community organisation and smallholder land tenure in Calakmul (Haenn 2006). Therefore, we focus on the ejidal sector to understand the dynamics of gendered changes in agricultural assets and labour out-migration for smallholder, semi-subsistence households in southeastern Mexico. Through two stories, we illustrate and assess the sudden and unexpected shifts that can occur in women's productive asset control (in this case, land and cattle) with different patterns of gendered labour migration. In rural Calakmul, agricultural assets remain central to generating viable livelihoods in the area, even as smallholder agriculture wanes under difficult economic and environmental conditions.

\footnotetext{
B. Schmook $(\bowtie) \cdot$ A. C. Méndez-Medina

El Colegio de la Frontera Sur (ECOSUR), Av del Centenario Km 5.5,

C.P. 77014 Chetumal, Quintana Roo, México

e-mail: bschmook@ecosur.mx, anmendez@ecosur.mx

C. Radel

Department of Environment \& Society, Quinney College of Natural Resources,

Utah State University, 5215 Old Main Hill, Logan, UT 84322-5215, USA

e-mail: claudia.radel@usu.edu
} 
There is ample evidence from studies around the world that men's labour migration leads to changes in the gendered division of agricultural labour. However, there has been little to no examination of the changes in the gendered allocation of productive assets within agriculture that might also accompany labour migration. Studies on changes in the gendered division of agricultural labour date back to Boserup (1970), who noted that in regions where men migrated for wage labour, women took over tasks that men had previously performed. In their review of studies on gender and migration, Pessar and Mahler (2003, p. 825) found a similar overall trend. From the findings of eight studies, they concluded that in most cases, " "traditional' rules governing work weaken as nonmigrant women and girls assume the tasks usually performed by the now-emigrant men and boys." More recently, a number of studies in Mexico (Radel et al. 2012; Riao and Keilbach 2009) and elsewhere (De Brauw et al. 2008) have questioned the inevitability of feminised agricultural labour resulting from men's out-migration. Moreover, we know even less about shifts in control over agricultural assets and inputs other than labour. We aim to address this gap through an examination of the changes in gendered agricultural asset rights and control resulting from different patterns of labour migration in Calakmul. We focus on two assets central to agricultural production in the region-land and cattle.

As state support for small-scale agriculture has diminished (Echánove and Steffen 2004; Gravel 2007), rural livelihood strategies in Calakmul have diversified (Radel et al. 2010). One response to the changing opportunities for and conditions of semisubsistence agricultural production has been the emergence of circular or temporary migration patterns over the last decade, similar to those found elsewhere in Mexico (Massey et al. 2002). Beginning around 2000, an increasing number of men travelled to the United States in search of wage work to generate remittances and cash savings (Schmook and Radel 2008). The absence of men (for just under a year to many years) carried potential implications for agricultural production and the social arrangements surrounding that production. Household engagement in labour migration that generated income also carried implications for household and individual asset accumulation and control, including those of land and cattle.

This chapter combines findings from three phases of research that we conducted in Calakmul. The study zone is a sub-area within the municipality, with historically higher chilli (jalapeño peppers) cultivation. In 2007, we surveyed 155 households in six villages, asking questions related to the agricultural impacts of men's labour migration and gendered land tenure patterns. We followed up on the survey with qualitative interviews in 2010 and 2011 in one ejidal village (Fig. 13.1). The 2010 interviews revealed a new labour migration pattern-younger women migrating to nearby cities, such as Playa del Carmen, and the subsequent investment by those women's households in land and cattle. In 2011, we initiated a second set of qualitative interviews to better understand the relationship between women's internal labour migration and land and cattle acquisition. 


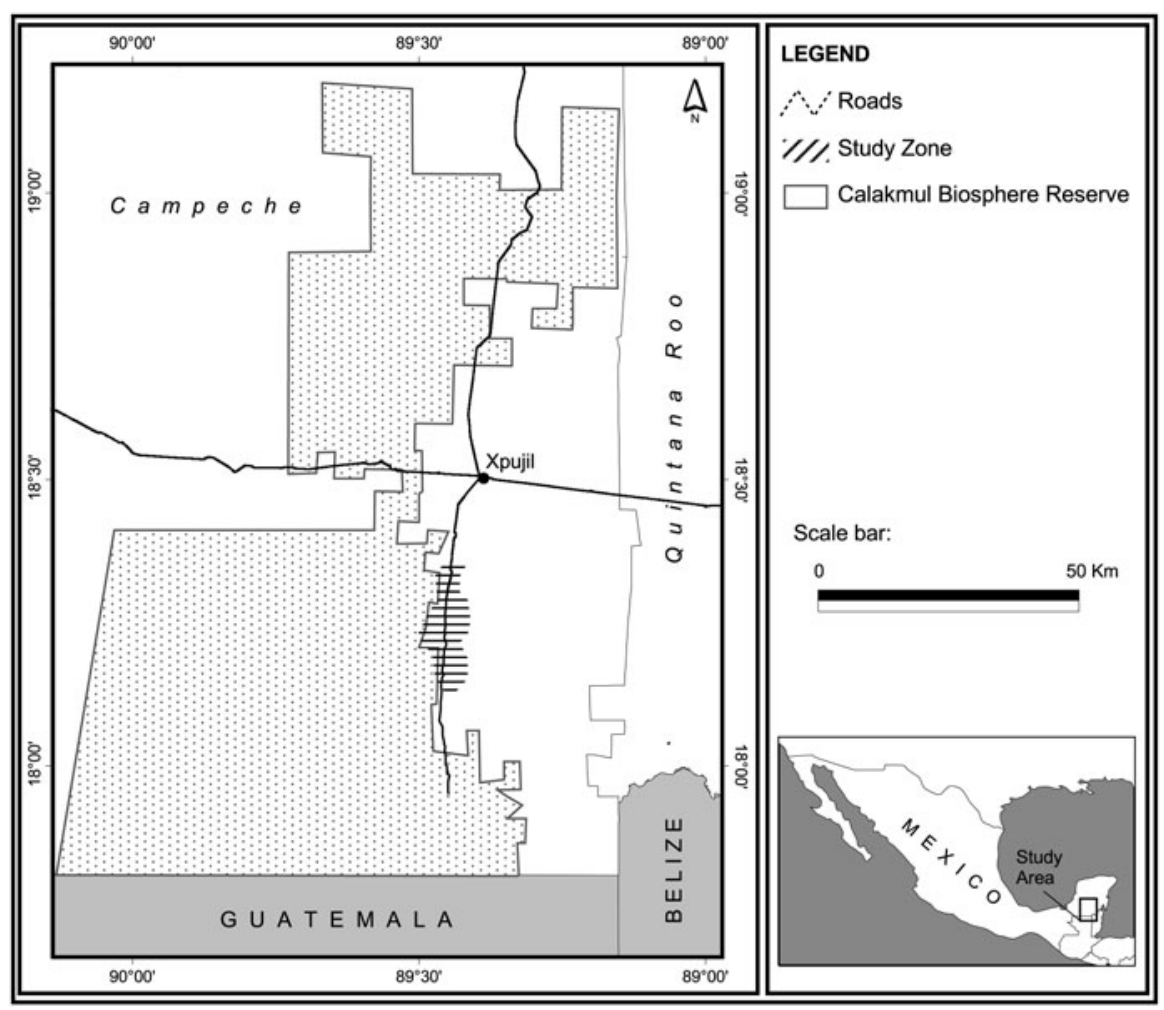

Fig. 13.1 The study sub-area within Calakmul. (Source: Radel et al. 2012)

\subsection{Labour Migration, Gender, and Productive Assets: A Review of the Literature}

Numerous scholars have documented the impacts of labour migration on household productive assets, but little of this work has detailed the intra-household division of these assets. Many case studies of remittances and migration earnings have primarily documented their use in terms of household consumption and housing versus the acquisition of productive assets (e.g., Basok 2000). In contrast, Sana and Massey (2005) argue that in Mexico a cohesive patriarchal family funnels migration earnings into local productive investments for household risk diversification. In addition, de Haas (2005) argues that the notion that remittances are primarily spent on conspicuous consumption and non-productive investments is a myth, founded on "a rather poor empirical and analytical basis" (p. 1274): Migrant households are often more likely to invest in productive enterprises than non-migrant households (De Haas 2005; Taylor et al. 1996).

Investment of remittances in cattle is one of the preferred economic options in Calakmul (Schmook and Radel 2008). Busch and Vance (2011), in their article on the 
diffusion of cattle in the region, conclude that cattle ranching is spreading, as it is well suited for households with abundant land, but often facing labour constraints. Labour constraints can typically be found in households with male migrating members. The same authors state that cattle ranching is less risky and can therefore reduce household vulnerability, given unfavourable conditions for crop production because of shallow soils and unpredictable climate variability. Another trigger for cattle ranching is support from government programmes. Even money from the "Farmers Direct Support Program" ("Programa de Apoyos Directos al Campo", PROCAMPO), initially designed for basic staple production (Schmook and Vance 2009), can now be invested in pastureland. In addition to remittance investment, several households have invested other income (e.g., from chilli cultivation) to cover the start-up costs of cattle ranching (Busch and Vance 2011).

The intra-household re-allocation of existing assets or the allocation of new assets is central to any understanding of the gendered impacts of labour migration on a household's productive assets and economic wellbeing. Underlying our analysis is an understanding of households as being more complex than cooperative units of consumption and production. Although a unitary model of the household, in which members are treated as if they have the same preferences and pool resources (Quisumbing 2003), is widely employed in economics and other social sciences, scholars of feminist economics have pioneered a more complex conceptualisation of the household (Folbre 1986; MacDonald 1995). The alternative model we adopt is best characterised as one in which gender cooperation accompanies individual interests (Jackson 2007). In economics, this is often referred to as the cooperative conflict household model (Sen 1987). Although the household, or family, is conceived as sharing common interests, each individual member also has interests that may at times conflict with those of other members. A woman's control over productive assets has important implications for her position within the family and the community and for her ability to further her individual interests.

Boserup (1970) expresses concern over the deterioration of women's rights to land that accompanied land privatisation, particularly under European colonisation and land reform. The concern over women's rights to land, especially under land reform, has abided for scholars three to four decades later (Casolo 2009; Jacobs 2009; Razavi 2003, 2007; Sargeson 2008). In her work on women and land in South Asia, Agarwal (1994) argues for formal land rights to empower women, and Deere and León (2001) have made the same argument for women's land control in Latin America. As land provides women with resources and choices, it thereby alters the power relations within the household. Some scholars have questioned the power of de jure land rights per se to transform gender relations (Jackson 2003), arguing that effective land control is more likely to lead to women's gender empowerment (Radel 2005). In this chapter, we examine both de jure land rights and effective land control, using land decision making as an indicator of effective land control.

Compared to research on women and land rights, very little research exists on women and livestock rights. Most of this research comes out of pastoral societies, especially in sub-Saharan Africa (Curry 1996; Hodgson 1999; Mkutu 2008; Oboler 1996). In a study conducted in the state of Veracruz, Mexico, Vázquez-García 
(2003) argues that women's ownership of cattle leads to their increased participation in household decision making over income expenditures, in the same way land ownership does.

\subsection{Methods}

The research documented in this study was conducted in three phases in a sub-area of the Calakmul municipality (Fig. 13.1). The ejidos there are relatively land rich, compared to elsewhere in Mexico. The six study ejidos have an extent of approximately 3,000 to 5,000 ha each. ${ }^{1}$ Parcel sizes allocated to ejidatarios/as (official ejidal rights holders, including to ejidal land) also vary across the ejidos, ranging from 20 to 50 ha. The majority of these ejidatarios are men, as elsewhere in Mexico. In 2002, only $10 \%$ of ejidatarios in a sample of 38 Calakmul ejidos were women (Radel 2005). This figure is lower than the $23 \%$ rate reported for the country as a whole (Amaya Quiroz 2007).

The first phase of research consisted of a random-sample household survey across all study ejidos. We selected 155 households, with the sample stratified by ejido and household migration status. These 155 households represented $37 \%$ of all households across the six ejidos (INEGI 2006). Migration status was defined in three categories: 55 households with no member having participated in transnational labour migration (non-migrant), 61 households in which the male head had at least one labour migration experience (migrant male head), and 39 households in which some other member (but not the male head) had at least one labour migration experience (other migrant member). To collect data from the surveyed households, we conducted oral interviews with both the male and female heads whenever possible.

To compare households with migrant male heads to those without migrant male heads, we created a category of 94 households with non-migrant male heads by combining the "non-migrant" and "other migrant member" groups. To ascertain our ability to combine these two sample stratification classes, we first examined the results of cross-tabulations to confirm the lack of statistically significant differences between these two groups for the key variables of interest. We then performed cross-tabulations for male and female de jure land rights and for women's reported participation in land-use decision making.

The second phase of research consisted of follow-up qualitative interviews, in late 2010 and early 2011, in Villanueva, ${ }^{2}$ one of the six ejidos. These interviews allowed us to validate and interpret the household survey findings on women's land rights.

A third phase was motivated by our learning that increasing numbers of household members, especially younger, unmarried daughters, had begun to migrate to the

\footnotetext{
${ }^{1}$ One of the surveyed ejidos covers only 626 ha, according to Mexico's Registro Agrario Nacional, but this extent is an outlier relative to the others in the study.

${ }^{2}$ We have changed the names of all individuals and ejidos to protect the confidentiality of participants.
} 
tourist corridor of Quintana Roo along the eastern coast of Mexico's Yucatan peninsula (including the cities of Playa del Carmen and Cozumel). In this third phase during the summer of 2011, one of the authors conducted 32 in-depth interviews of household members in Villanueva, mostly mothers, with migrating children in the tourist corridor and of the migrant children, mostly daughters, in Playa del Carmen. In addition, we "inventoried" nearly half (36) of the households in Villanueva to collect additional data on household members who have been, or currently are, labour migrants to the United States, to the tourist corridor, or to elsewhere in Mexico. We present this quantitative "inventory" information on the 36 Villanueva households in the form of descriptive percentages to demonstrate the importance of the new migration destinations and the household use of the resultant remittances. Finally, we conducted a brief workshop in Villanueva with girls aged 14 to 20, asking them to write down their goals in life and what they would like to do in the next three years.

Established in 1983, Villanueva is a product of rural to rural migration within Mexico. Most residents came in search of farmland from the neighbouring states of Chiapas and Tabasco and consider themselves mestizo in terms of ethnic identity. Male out-migration began here in 2002. By 2007, over half of the male headsof-households had migrated to the United States for at least some period of time. Residents cited the lack of local job opportunities and crop failures as the primary causes of labour migration. By 2010 and 2011, we observed fewer and fewer community members migrating to the United States. Instead, new migrants had begun to head to close-by Mexican destinations. According to several informants, the reasons for this shift in the labour migration pattern included the growing difficulties of the border crossing to the U.S. due to intensified border control and the growing cost of the crossing. Increasingly, migration to the United States is considered permanent or long-term, as going back and forth to Mexico is perceived as being too dangerous and expensive. However, informants state that migration to nearby tourist resorts is cheap and going back and forth to the home village is easy. Young women find the tourist corridor an attractive labour destination, with employment available in stores and restaurants. Some of the migrant daughters stated that there are no adequate work opportunities for them in Villanueva, as agricultural work is neither desirable nor appropriate for them (see also McEvoy et al. 2012).

\subsection{Husbands' Migration and Wives' Land Assets}

The 2007 survey found that for households without migrant male heads, $10 \%$ of the women held ejidal land rights in their own names (de jure land control) (see Table 13.1). In contrast, for the surveyed households with migrant male heads, more than double the number of women $(24 \%)$ held ejidal land rights $\left(X^{2}=5.23\right.$, $p=0.02$ ). We also examined the association of migration with rates of ejidal land rights for the male household heads. Of the three categories of households (migrant head, other migrant member, and non-migrant households), migrant heads were the least likely to hold ejidal land rights. Only $56 \%$ of migrant heads held ejidal rights, 
Table 13.1 Household Survey Results, $2007(\mathrm{n}=155)$

\begin{tabular}{|c|c|c|c|}
\hline & $\begin{array}{l}\text { Husband is or has } \\
\text { been a U.S. migrant }\end{array}$ & $\begin{array}{l}\text { Husband is not and } \\
\text { never has been a U.S. } \\
\text { migrant }\end{array}$ & $\begin{array}{l}\text { Husband is not a } \\
\text { migrant, but another } \\
\text { household member is } \\
\text { or has been }^{\mathrm{a}}\end{array}$ \\
\hline \multicolumn{4}{|c|}{ De Jure Land Control: Ejidal Land Rights } \\
\hline \multirow[t]{2}{*}{ Wife holds rights } & $24 \%$ & $10 \%$ & \\
\hline & $\begin{array}{l}\text { Chi-square results } X^{2} \\
56 \%\end{array}$ & $\begin{array}{l}5.23, p=0.02 \\
62 \%\end{array}$ & $86 \%$ \\
\hline Husband holds rights & Chi-square results $X^{2}$ & $9.09, p=0.01$ & \\
\hline \multicolumn{4}{|c|}{ De Facto Land Control: Land-Use Decision Making } \\
\hline $\begin{array}{l}\text { Husband makes } \\
\text { planting decisions }\end{array}$ & $60 \%$ & $83 \%$ & \\
\hline $\begin{array}{l}\text { Wife makes planting } \\
\text { decisions }\end{array}$ & $15 \%$ & $1 \%$ & \\
\hline \multirow[t]{2}{*}{$\begin{array}{l}\text { Husband \& wife make } \\
\text { planting decisions } \\
\text { together }\end{array}$} & $25 \%$ & $16 \%$ & \\
\hline & Chi-square results $X^{2}$ & 4.123, $p=0.001$ & \\
\hline
\end{tabular}

${ }^{a}$ For the husband's holding of land rights, this stratification category of the sample was not combined with the non-migrant male head category; for all other variables, it was combined

while $62 \%$ of the male heads of non-migrant households held those rights and $86 \%$ of the male heads of households in which some other household member was a migrant held those rights $\left(X^{2}=9.09, p=0.01\right){ }^{3}$

As an indicator of effective (de facto) land control (Radel 2005), we also asked the male household head who decides if and what the household will plant on the land held by household members. For households without a male migrant head, in $83 \%$ of the cases the reported decision maker was the man, while in $16 \%$ it was the man and woman jointly, and in only $1 \%$ it was the woman (see Table 13.1). In contrast, for households with a migrant male head, in $60 \%$ of the cases the reported decision maker was the man, while in $25 \%$ it was the man and woman jointly, and in $15 \%$ it was the woman $\left(X^{2}=14.123, p=0.001\right)$. Women with migrant husbands thus were more than twice as likely to be reported as participating in planting decisions, either making the decision autonomously or together with her male partner.

The interviews in Villanueva revealed key insights into these survey results. In 2010, 20 of the 67 Villanueva ejidatarios/as ${ }^{4}$ were women (30\%). In 2002, only five of the 84 ejidatarios/as were women $(6 \%)$. What explains this increase and the positive association between wives' land tenure and their husbands' labour migration?

\footnotetext{
${ }^{3}$ For the categorical variable of whether the male household head had ejidal land rights, we did not combine the two non-migrant male head groups (non-migrant households and households with a migrant member other than the male head), as we found a statistically significant difference between the two groups.

${ }^{4}$ The list of 67 ejidatarios/as is that managed internally by the ejido; the list held by the Registro Agrario Nacional is slightly different.
} 
Many women in Villanueva became ejidatarias as a result of the certification of ejidal land rights under Mexico's PROCEDE process. In 1992, Mexico passed the New Agrarian Law and began the process of regularising, privatising, and documenting land rights in the countryside. The Registro Agrario Nacional (RAN, the National Agrarian Registry) was the federal state entity tasked with the PROCEDE process-a process that has taken nearly 20 years and is still not complete. The first step was the certification of ejidal rights. As reported by Villanueva residents, RAN officials visited the community in 2003 to conduct this certification and register the names of the individuals holding rights to ejidal land.

The general understanding in the community was that for the rights certification to occur, individuals needed to be present and of legal majority age. Ejidal rights that were not certified by RAN at that time would be forfeited and the land would be designated as common ejidal property. It remains unclear whether it was the RAN agents or particular community leaders who encouraged women to step forward in the place of absent men and underage sons. In any case, an expectation emerged in that moment that these women would become land-titled ejidatarias as caretakers for the land rights of men and soon-to-be men. As Reyna, an ejidataria and wife of a migrant, said,

Each has their [land] right and each knows why they have it. Perhaps I did not want to be an ejidataria, but I was obliged to become one when my husband left, leaving the land, as they say, abandoned. And as a result, they were going to give this land to the so-called common use. At a meeting they [the ejidatarios] supported me, because my husband was not present and one had to get this title so that one could have the [land] right that was for the family. So the ejidatarios supported me and for that reason I am an ejidataria.

Subsequently, however, considerable conflict emerged in the community and within households over the legitimacy and appropriateness of the land transfers to women. For those women whose husbands continue to be absent in the U.S. and are seen as having been abandoned, the larger community validates their status as ejidatarias. These women are referred to as "viudas"-widows. Women who hold the land rights "temporarily" for underage sons, while their husbands hold a separate set of rights, also receive validation in the community. One male migrant spoke of what he considered to be an appropriate case:

What happened was that when they did the registration, some [men] were not warned, and for this reason they did all these registrations, for this reason there are so many women ejidatarias. Although it is good, for example, in the case of my sister, because her husband still has not returned, and thus in this case it was good.

However, for those women whose husbands did return to the community, the land transfers have been considered usurpations of men's rights. As another male migrant expressed:

What happened is that when RAN came in 2003, many husbands were away and some women took advantage to transfer the [land] rights into their names; so to speak, they came to possess the right of their husbands. In the case of my wife, she didn't want to and my title came to me, but other women yes took advantage; as one might say, they dispossessed the men. 
In at least one case, the perception of male land dispossession contributed to the dissolution of the marriage. One migrant's wife who effected a transfer in her husband's absence spoke of her experience:

\begin{abstract}
The problems deepened when I changed the ejidal right into my name. He said to me very angrily that now that I had robbed him of his land, if he returned he would have nothing here. He said to me, 'if I return I will be your man servant, you will hire me.' I told him that the only thing I had done was to protect the right for his children. If I had not put it [the land] into my name, they were going to convert it into communal land, but that when he returned they would put it into his name again. But he said he could not ignore what I had done, and he told me he didn't want anything to do with me-that I should live my life as I see fit. I telephoned him several times and was crying, but he didn't want to be with me anymore.
\end{abstract}

The implications of shifts in the gendered distribution of land control are potentially significant, at both the community and household levels. These shifts are visible in terms of the wives' increased participation in land-use decision making and in terms of their increased likelihood of holding formal rights to ejidal land. The survey results show that male household head migration is associated with higher rates of (1) women's participation in deciding what and how much to cultivate, either autonomously or together with her husband, and (2) women's formal holding of ejidal land rights. Together, these findings suggest that men's labour migration has led to greater de facto and de jure control of land in some Calakmul villages. Women's de jure land control, although not always associated with effective land control (Radel 2005), suggests women's potentially decreased dependence on men to access and mobilise land and development resources. In Villanueva, the recognition that de jure rights have real meanings in terms of power and community standing has led to considerable conflict over the shift of rights from men to women. Ejidal rights are more than just rights to land as a productive asset; they also accord a sanctioned voice in community decision making and in the distribution of community resources, including incoming benefits from development and poverty-alleviation projects. However, to the extent that women simply hold these rights on behalf of men and underage sons, with control and voice vested instead with husbands and in-laws, the gendered transfer of land rights carries little to no change in broader gender relations within households and the community.

\title{
13.5 Daughters' Migration and Daughters' Land and Cattle Assets
}

Even as men's U.S. labour migration began to decline, migration remained a significant aspect of household livelihood strategies in many Calakmul villages. As male heads of households have increasingly returned from the U.S., the remittances of migrant sons and daughters have become the key source of migration earnings. In 2011, $68 \%$ of the inventoried households in Villanueva had at least one migrant child, whether in the U.S., the tourist corridor of Quintana Roo, or elsewhere (Table 13.2). Half of all households had at least one migrant child in the tourist 
Table 13.2 Households with migrant children, with destinations $(\mathrm{n}=36)$
Table 13.3 Children's migration destinations, by gender $(n=168)$

\begin{tabular}{lll}
\hline & Number $^{\mathrm{a}}$ & Percentage \\
\hline $\begin{array}{c}\text { Households with migrant child(ren) in } \\
\text { the United States }\end{array}$ & 12 & $35 \%$ \\
$\begin{array}{c}\text { Households with migrant child(ren) in } \\
\text { the Tourist Corridor of Quintana Roo }\end{array}$ & 17 & $50 \%$ \\
$\begin{array}{c}\text { Households with migrant child(ren) } \\
\text { elsewhere in Mexico }\end{array}$ & 16 & $47 \%$ \\
$\begin{array}{c}\text { Household with migrant child(ren) in } \\
\text { any destination category }\end{array}$ & 23 & $68 \%$ \\
\hline
\end{tabular}

${ }^{\text {a }}$ Households sum to more than 36 , as a given household can be in more than one category

\begin{tabular}{|c|c|c|c|}
\hline & Sons & Daughters & Total \\
\hline Migrant children to the United States & 18 & 1 & 19 \\
\hline $\begin{array}{l}\text { Migrant children to the Tourist } \\
\text { Corridor of Quintana Roo }\end{array}$ & 9 & 21 & 30 \\
\hline $\begin{array}{l}\text { Migrant children to elsewhere in } \\
\text { Mexico }\end{array}$ & 10 & 18 & 28 \\
\hline $\begin{array}{l}\text { Migrant children to any of the three } \\
\text { destination categories }\end{array}$ & 37 & 40 & 77 \\
\hline
\end{tabular}

corridor, and these migrants often were daughters (Table 13.3). $47 \%$ of all inventoried households had daughter(s) and/or son(s) in other parts of Mexico, such as the nearby city of Chetumal, where the daughters work as domestic servants, in stores or in restaurants.

An examination of the destinations for all son and daughter labour migrants demonstrates a clear difference by gender. Sons are just as likely to travel to the U.S. as they are to remain in Mexico. Daughters, however, are just as likely as sons to be labour migrants but rarely travel outside Mexico (Table 13.3). Of the 168 total children in all 36 households, 77 (or $46 \%$ ) are migrants, and 40 of those are daughters.

Of the 36 households inventoried, 16 reported receiving remittances from migrant daughters. Only two households reported receiving remittances exclusively from sons, and 18 reported not receiving remittances from a migrant child. The interviewees also specified that it is mainly daughters who remit funds to Villanueva, with sons often expected to save for the establishment of their own households. Most $(69 \%)$ of these 16 households receiving remittances from daughters reported using the remittances for household expenses in general or for household consumption (Table 13.4). However, $44 \%$ of households invested remittances in land. In this category we include land purchases, including agricultural lands or lots within villages or towns, and/or the purchase of agricultural inputs. As some migrant daughters left their young children with grandparents, $38 \%$ of the households reported using the remittances specifically to feed or otherwise provide for their grandchildren. Investment in cattle was another important reported use of remittances among $19 \%$ of the households. 
Table 13.4 Use of

Remittances by Households with Labour Migrant Daughters, $2011(\mathrm{n}=16)$

\begin{tabular}{lll}
\hline & $\begin{array}{l}\text { Number }{ }^{\mathrm{a}} \text { of } \\
\text { households } \\
\text { reporting use }\end{array}$ & $\begin{array}{l}\text { Percentage of } \\
\text { households } \\
\text { reporting use }\end{array}$ \\
\hline $\begin{array}{l}\text { Investment in land } \\
\text { Investment in cattle }\end{array}$ & 7 & $44 \%$ \\
$\begin{array}{l}\text { Improvement of house } \\
\text { Investment in agricultural }\end{array}$ & 1 & $19 \%$ \\
$\quad$ implements, car, & 2 & $6 \%$ \\
$\quad$ motorcycles among others & & $13 \%$ \\
$\begin{array}{l}\text { Household consumption in } \\
\quad \text { general }\end{array}$ & 11 & $69 \%$ \\
$\begin{array}{l}\text { Caring for child(ren) of the } \\
\quad \text { migrant(s) }\end{array}$ & 6 & $38 \%$ \\
\hline
\end{tabular}

${ }^{\text {a }}$ Several families reported several of the uses

The new generation of young residents is migrating to Playa del Carmen, Cancun and Cozumel without risking their lives crossing the border to the United States and becoming indebted. Mercedes, now back in Villanueva, told us the following:

... it is very difficult to get there [to the U.S.], to what they call the border. Also you have to see that they killed a lot of Mexicans, and therefore they are scared and don't go. One says I am going [to the U.S.] to improve [economically] and it happens that they kill you or something else; they say, therefore I better stay. Also you see that they suffer a lot crossing, because there is a lot of border control and they [the middlemen] charge. When my brother left they charged him 20,000 pesos .... But it is not very complicated to get there [to Playa del Carmen], you take an ADO [a local bus company] and you pay like 320 pesos and you arrive at the bus terminal and from there you take a taxi for 50 pesos.

Young women, who are finishing secondary school and are not ready to get married, often consider the possibility of working in the tourist corridor. This decision is possible because of relatives already living there, and hence young women in particular stay with relatives. Nineteen-year-old Valentina explains how she left Villanueva to visit a sister in Playa del Carmen, after having had to drop out of school. She remained in the city to work:

I was studying, but as I told you it was very difficult back then for me to get from here [Villanueva] to the other village [with a high school]. There was no [public] transport and one had to walk.... Therefore my father said that I better don't study.... So I took the chance, as my sister came from Playa and asked me if I would like to go there for a vacation. It was like that, that I started to work and stay there.

In addition, single mothers who need to provide for young children often migrate to the tourist corridor. These young women, seeking to contribute to household income, do not consider unpaid work in agriculture or domestic chores to be a viable option. Moreover, paid labour in Villanueva is only available to men. As one young single mother explained,

I did send money to my child, who was with my mother. . as you see the situation here is difficult. For example, here we only have work for men, in the fields, and they pay 100 pesos [a day] for whatever work.... In the city it is different. There men and women can work, and here only men work and one doesn't. I was bored and I wanted to work, but we are in the countryside and there is no work.... 
Many young women's aspirations can no longer be met in Villanueva. Most are not satisfied with the prospect of farming. The following quotes are from a workshop we conducted with girls (ages 14-20) in Villanueva, where we asked the girls to write down their life goals and what they would like to do in the next three years:

\begin{abstract}
I would like to finish school to be someone in life. I would like to do my bachelors in law or infant sociology. And if I can't reach my goals, I would rather call them my dreams. And if I can't finish school, what can I do? But it won't be my fault if I don't. I try. I have seen that some people don't find [work] or nobody offers them work because they did not finish school, and others how they work in the countryside. I don't like to work in the fields, ... and therefore I will put a lot of effort to finish school because I want to study. (a 15-year-old participant)

I would like to finish middle school in the next three years and be with my uncles and my cousin and afterwards leave the village with them. And I would like to work in Playa or in some other place and help my uncles and myself moving ahead [improving our lives]. (another 15-year-old participant)
\end{abstract}

However, the young women migrants (and would-be future migrants) are not simply abandoning agricultural livelihoods; on the contrary, we found new ways in which migrant daughters participate in agricultural production. The 2003 land titling of women in Villanueva has opened new perspectives and possibilities for young women. Migrant daughters consider the possibility of owning their own cattle or a piece of land. Young unmarried women contribute to the household's income and agricultural decision making, and some continue to do so even after they marry. One mother told us that the family used the money her daughter, Candela, remitted to buy a calf. It was the family who suggested buying that first calf. Candela liked the idea, and she subsequently bought more cattle. Now she owns seven heads of cattle. Candela subsequently married and then began to save part of the money her husband gave her for daily expenses. With it she bought land in Villanueva to establish her ranch, and she gave 7000 pesos to her parents so that they could be shareholders in a tractor. Candela also sends money to her parents so they can buy "medicine" for her cattle. She also bought a piece of land in the village, where she wants to live when she grows old. Her mother has two more migrant daughters, who also saved money and own seven heads of cattle, and remit funds for cattle maintenance.

Buying land has become a form of investment, opening new possibilities for young women. A daughter in another family, Mariana, went to Chetumal to finish school and work and purchased a village lot with the money she saved. She and her mother cultivate chilli, with her mother in charge of the land and cultivation, while Mariana studies in the nearby town of Xpujil through a recently opened, on-line university. Most often, it is the single daughters who maintain strong links with their parents and remit money. Until they marry, these migrant daughters are the central pillars of the household economy:

My sister paid for my ticket, the one who lives in Playa, she came [to Villanueva], she came this day in July to graduation and she told me let's go. We went and as she was still single, I said yes.... As they paid me 1500 pesos, and sometimes with extras I earned 2000 pesos a week, I sent 1000 pesos to my mother or 1500 . . . every week. . . Afterwards, as I got 5000 pesos from a rotating saving group], it was my father who told me that we should buy cattle. It was back then when I started to save my money. 
Female participation in household asset accumulation is changing dramatically. The migrant daughters do not participate directly in the labour of cattle ranching, considered a difficult and male task, but they actively participate in the creation of family assets that are then key to the household's agricultural production. With the help of the daughters' remitted earnings, agriculture remains a viable activity. Interviewees often spoke of land and cattle as "belonging" to the migrant daughter, but the daughters' control of the assets often remains partial and conditional. Assets purchased with daughters' remittances remain with the original household when the daughters marry. Once married, the husband is expected to provide for the newly formed household. At the time of the interviews, Valentina owned 11 of the 50 cattle on the family ranch. Her sister owned six of the cattle, which she purchased prior to being married. The daughters would send money they saved from their wages to their mother in Villanueva, where the decision of how to use the money was made. Their father decided to buy a plot of land for one of the girls' brothers. The father told the daughters that he purchased the lot for the son because the daughters would belong to their husbands and would live where their husbands wanted, but sons needed land to bring to their wives. Valentina told us how her father sold cattle belonging to her and her sister to help pay for her brother's land:

My father had to sell 10 yearling calves ... because he was going to buy the lot here and an agricultural parcel, and this required that he sell some of my calves and some of my sister's. And he asked us also when he went to conduct the business, he asked us if we were in agreement. We said we would tell him yes or no, but meanwhile don't sell the animals.

However, the father did sell the cattle, demonstrating that the young women's interests in their cattle were secondary to general household interests defined by the father. The women's labour was converted to cattle assets, which were then transferred into land assets in their brother's name.

\subsection{Conclusions}

We have found that both self-migration and the migration of other family members can lead to the accumulation of productive agricultural assets for women. However, their rights to these assets remain contested and conditional, shaped by gender norms and ideologies that are changing more slowly than are the economic conditions facing the women and their families. These economic conditions drive (in a negative sense) and enable (in a positive sense) the asset accumulation of the women by requiring wage labour migration for household survival and opening opportunities for women in a variety of ways-both expected and unexpected. In this respect, our research deepens, extends, and contrasts Boserup's observations and concerns over similar processes she observed unfolding in rural agricultural areas of the global south in the context of European colonisation and land reform decades ago.

In the story of the wives of U.S. migrants and the transfer of land rights under PROCEDE, the women's locally recognised right to the land now in their names is conditional on their holding the land for under-age sons and absent husbands. 
In other cases, many in the community regard their land rights as a usurpation of men's rights. In this sense, the de jure land rights have not improved the position of new women rights-holders in their households and communities, in contrast to much existing theory on women's land rights. Women remain proxies for men or their rights are delegitimised in the local ejido context. Thus we should not be surprised if the translation of women's land rights as certified ejidatarias into women's empowerment is partial at best. We also observed an increase in women's participation in landuse decision making, which represents a key aspect of effective land control. In earlier research in Calakmul, Radel (2005) argued that effective land control is more pertinent to women's gender empowerment in these villages than de jure land rights. In addition, a change in the percentage of ejidatarios who are women-from only six to $30 \%$ - can change what a new generation of women consider possible and may well have played some part in paving the way for migrant daughters' acquisition of village land in the second story we relate here. The changes in women's land rights and control in Villanueva has a complex relationship with women's position within the community-neither simply and automatically improving that position for the women directly in question, nor having no meaning at all in the larger scheme of changing gender norms and ideologies.

In the migrant daughters' story, female participation in household asset accumulation is changing dramatically. The land and cattle acquired with daughters' remittances are additions to a household's portfolio of assets and, in contrast to the first story, do not represent intra-household transfers. Although the young women's asset rights are often conditional on remaining a part of the household and not marrying, in most cases the daughters' interests within the household do not conflict with the interests of other household members. In some households, however, interests are in conflict and asset control is contested, with the young women's asset rights subject to possible re-assignment to another family member, such as a brother. As Sana and Massey (2005) found elsewhere in Mexico, a cohesive patriarchal family can effectively funnel migration earnings into local productive investments for household benefit. However, as we have demonstrated, this outcome does not always best benefit women in the household. Finally, the acquisition of cattle, in particular, by migrant daughters raises the need for more empirical research to understand whether cattle ownership can play a role in the household positions of female members in a manner similar to the role that land has been theorised to play.

A comparison of the two asset shifts described in this chapter yields a number of potentially important differences. First, the nature of the asset shift differs. In the first case, there were intra-household transfers; in the second case, the assets were new additions to a household portfolio. This impacts the types of intra-households conflicts generated. Second, the gendered nature of the associated labour migration and its location differs. In the first case, the migrants were male household heads who were unable to return quickly; in the second case, the migrants were the women themselves who worked relatively close-by. These differences shaped the ease of return and the migrant's ability to "claim" particular assets. Third, the initial household positions of the women in question varied, with the most generalisable difference being that of wives versus daughters. This initial position clearly matters in the outcomes of 
subsequent asset shifts, although the notion that the daughters would become wives in other households also clearly shaped the intra-household dynamics. Fourth, the nature of the asset itself differs. In the first case, the assets were ejidal lands; while in the second case, the assets primarily were fully privatised land lots (village house lots and private lots) and/or cattle. We would expect ejidal land rights to be much more contested because they are accompanied by a voice in ejidal governance and other sorts of financial and non-financial benefits. Together, these differences shaped the outcomes for the women and are important, therefore, in our understanding of the relationship between gendered asset shifts and local gender relations.

In conclusion and despite all of the cautions and caveats, we believe that shifts in women's role in agricultural asset decision making and tenure in Calakmul, even when partial and conditional, matter-but the degree to which they matter remains an open question. New roles in the control of productive agricultural assets such as land and cattle can open further space for the construction of new gender identities and transformations in gender relations within households and communities. To understand these possibilities, we must continue to be detailed in our examination of shifts in women's control over productive assets to improve our understandings of when, which, and to what degree shifts do and do not improve the positions of women within households and communities.

Acknowledgments The content in this chapter is drawn partly from our article published in 2012 in the Journal of Agrarian Change (vol. 12, issue 1, pp. 98-119). We would also like to thank all of the interviewees for the generous gift of their time.

Open Access This chapter is distributed under the terms of the Creative Commons Attribution Noncommercial License, which permits any noncommercial use, distribution, and reproduction in any medium, provided the original author(s) and source are credited.

\section{References}

Agarwal, B. (1994). A field of one's own: Gender and land rights in South Asia. Cambridge: Cambridge University Press.

Amaya Quiroz, S. E. (2007). 'Ya ganamos las mujeres.' La UAIM en Salvatierra, una realidad poco explorada. In R. Rosas Vargas \& E. Zapata Martelo (Eds.), Mujeres en la Bruma. Tenencia de la Tierra en Guanajuato. Mexico: México Consejo Nacional de Ciencia y Tecnología, Consejo de Ciencia y Tecnología del Estado de Guanajuato, Instituto de la Mujer Guanajuatense, Colegio de Posgraduados.

Basok, T. (2000). Migration of Mexican seasonal farm workers to Canada and development: Obstacles to productive investment. International Migration Review, 34(1), 79-97.

Boserup, E. (1970). Woman's role in economic development. New York: St. Martin's Press.

Busch, C., \& Vance, C. (2011). The diffusion of cattle ranching and deforestation: Prospects for a hollow frontier in Mexico's Yucatán. Land Economics, 87(4), 682-698.

Casolo, J. (2009). Gender levees: Rethinking women's land rights in Northeastern Honduras. Journal of Agrarian Change, 9(3), 392-420. 
Curry, J. (1996). Gender and livestock in African production systems: An introduction. Human Ecology, 24(2), 149-160.

De Brauw, A., Li, Q., Liu, C., Rozelle, S., \& Zhang, L. (2008). Feminization of agriculture in China? Myths surrounding women's participation in farming. The China Quarterly, 194, 327-348.

De Haas, H. (2005). International migration, remittances and development: Myths and facts. Third World Quarterly, 26(8), 1269-1284.

De Janvry, A. G., \& Sadoulet, E. (1997). Mexico's second agrarian reform: Household and community responses. San Diego: University of California.

Deere, C. D., \& León, M. (2001). Empowering women: Land and property rights in Latin America. Pittsburgh: University of Pittsburgh Press.

Echánove, F., \& Steffen, C. (2004). Coping with trade liberalization: The case of Mexican grain producers. Culture and Agriculture, 25(2), 31-42.

Folbre, N. (1986). Hearts and spades: Paradigms of household economics. World Development, 14(2), 245-255.

Gravel, N. (2007). Mexican smallholders adrift: The urgent needs for a new social contract in rural Mexico. Journal of Latin American Geography, 6(2), 77-98.

Haenn, N. (2006). The changing and enduring ejido: A state and regional examination of Mexico's land tenure counter-reforms. Land Use Policy, 23, 136-146.

Hodgson, D. L. (1999). Pastoralism, patriarchy and history: Changing gender relations among Maasai in Tanganyika,1890-1940. The Journal of African History, 40(1), 41-65.

INEGI (Instituto Nacional de Estadística, Geografía e Informática). (2006). Censo general de población y vivienda, 2005. Resultados definitivos. Datos por localidad, Campeche. Aguascalientes: INEGI.

Jackson, C. (2003). Gender analysis of land: Beyond land rights for women? Journal of Agrarian Change, 3, 453-480. doi:10.1111/1471-0366.00062.

Jackson, C. (2007). Resolving risk? Marriage and creative conjugality. Development and Change, $38(1), 107-129$.

Jacobs, S. (2009). Gender and land reforms: Comparative perspectives. Geography Compass, 3(5), $1675-1687$.

Macdonald, M. (1995). Feminist economics: From theory to research. The Canadian Journal of Economics, 28(1), 159-176.

Massey, D., Durand, J., \& Malone, N. (2002). Beyond smoke and mirrors: Mexican immigration in an age of economic integration. New York: Russell Sage Foundation.

McEvoy, J., Petrzelka, P., Radel, C., \& Schmook, B. (2012). Gendered mobility and morality in a south-eastern Mexican community: Impacts of male labour migration on the women left behind. Mobilities, 7(3), 369-388. doi:10.1080/17450101.2012.655977.

Mkutu, K. A. (2008). Uganda: Pastoral conflict \& gender relations. Review of African Political Economy, 35(116), 237-254.

Oboler, R. S. (1996). Whose cows are they, anyway? Ideology and behavior in Nandi cattle 'ownership' and control. Human Ecology, 24(2), 255-272.

Pessar, P., \& Mahler, S. (2003). Transnational migration: Bringing gender in. International Migration Review, 37(3), 812-846.

Quisumbing, A. (Ed.) (2003). Household decisions, gender, and development. Washington, DC: International Food Policy Research Institute.

Radel, C. (2005). Women's community-based organizations, conservation projects, and effective land control in southern Mexico. Journal of Latin American Geography, 4(2), 9-36.

Radel, C., Schmook, B., \& Roy Chowdhury, R. (2010). Agricultural livelihood transition in the Southern Yucatán Region: Diverging paths and their accompanying land changes. Regional Environmental Change, 10(3), 205-218.

Radel, C., Schmook, B., McEvoy, J., Méndez, C., \& Petrzelka, P. (2012). Labour migration and gendered agricultural relations: The feminization of agriculture in the ejidal sector of Calakmul, Mexico. Journal of Agrarian Change, 12(1), 98-119. 
Razavi, S. (2003). Introduction: Agrarian change, gender and land rights. Journal of Agrarian Change, 3(1/2), 2-32.

Razavi, S. (2007). Liberalisation and the debates on women's access to land. Third World Quarterly, 28(8), 1479-1500.

Riao Marín, R. E., \& Keilbach Baer, N. M. (2009). Mujeres y nueva ruralidad: Un estudio de caso sobre la desfeminización de la agricultura. Sociedades Rurales, Producción y Medio Ambiente, 9(18), 79-108.

Sana, M., \& Massey, D. (2005). Household composition, family migration, and community context: Migrant remittances in four countries. Social Science Quarterly, 86(2), 509-528.

Sargeson, S. (2008). Women's property, women's agency in China's 'new enclosure movement': Evidence from Zhejiang. Development and Change, 39(4), 641-665.

Schmook, B., \& Radel, C. (2008). International labour migration from a tropical development frontier: Globalizing households and an incipient forest transition-the Southern Yucatán case. Human Ecology, 36(6), 891-908.

Schmook, B., \& Vance, C. (2009). Agricultural policy, market barriers, and deforestations: The case of Mexico's Southern Yucatán. World Development, 37(5), 1015-1025.

Sen, A. (1987). Gender and cooperative conflicts. Working Paper, no. 18. Helsinki, Finland: World Institute for Development Economics Research. Helsinki.

Taylor, J. E., Arango, J., Hugo, G., Kouaouci, A., Massey, D. S., \& Pellegrino, A. (1996). International migration and community development. Population Index, 62(3), 397-418.

Vázquez-García, V. (2003). Whose money is it? Cattle production and household income allocation in southern Veracruz, Mexico. International Journal of Agricultural Resources, Governance, and Ecology, 2(2), 140-152. 